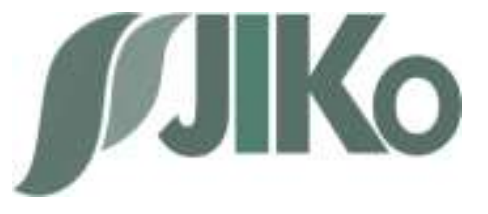

\title{
Effect of entrepreneurial orientation and knowledge sharing on business performance
}

I Gede Eko Putra Sri Sentanu'; Ardik Praharjo ${ }^{2}$

Department of Public Administration, Universitas

Brawijayal, Indonesia ${ }^{1}$

Departmen of Managemen, Universitas Muhammadiyah Malang ${ }^{2}$

Received:26-11-2019 | Revision: 16-12-2019 | Accepted: 31-12-2019

\begin{abstract}
This study aims to determine the effect of entrepreneurial orientation and knowledge sharing on innovation and business performance on creative industry-based SMEs in Malang City. Entrepreneurial orientation is very important because the creative industry currently has an important role in building the economy. The type of research used is explanatory research using hypothesis testing and quantitative approaches. The number of samples in this study amounted to 57 respondents who were creative industry-based SMEs in Malang City. The research uses descriptive statistics and path analysis. The results of the study show that there is a significant influence between entrepreneurial orientation and knowledge sharing on business performances with innovation capability as a mediating variable.
\end{abstract}

Keywords: Entrepreneurial orientation; knowledge sharing; innovation capability; business performance

\section{Introduction}

The development of Small and Medium Enterprises (SMEs) has been proved to increase gross domestic product (GDP) and reduce unemployment in Indonesia (Suliswanto \& Rofik, 2019). Based on data from Trading Cooperatives and Small and Medium Enterprises in 2017, the contribution of the SME's sector increased from 57.84 percent to 60.34 percent. The SME sector has also helped absorb employment in Indonesia. Absorption of labor in the SME sector grew from 96.99 percent to 97.22 percent in the last five years (Depkop.go.id). Factors needed to create SME activities were the existence of creative ideas, innovation, knowledge about entrepreneurship, and so forth. With the presence of original design, SME's businesses can continue to run and compete with other competitors such as companies and other SMEs. An innovative product will become an entrepreneurial orientation trait for SMEs themselves (Asegaf and Wasitowati, 2015)

Bhadwadwaj et al. (1993) explain that entrepreneurial orientation is a strategy implementation that utilizes various resources owned by SMEs. Unique expertise and assets are seen as sources of competitive advantage. Unique expertise is the ability of SMEs to make their employees an important part in achieving good performance and innovation. To win a competition, companies need to apply entrepreneurial orientation so that they can create the ability to innovate (Wood et al., 2004). According to Wood et al. (2004), entrepreneurial orientation is the ability to channel creative innovation in

\footnotetext{
${ }^{1}$ sentanu@ub.ac.id
} 
businesses that have more value. Entrepreneurial orientation is considered a critical process of the organization that contributes to the company's survival and performance.

Knowledge will be very useful if divided within an organization. According to Preda (2013) knowledge dissemination is the process by which knowledge is shared within the organization. Knowledge interpretation is the process by which information is given meaning. Organizational memory means that knowledge is stored for future use. This knowledge is used to identify market opportunities and to provide new and superior values. According to Fen Lin (2007) knowledge sharing is divided into two dimensions, namely knowledge collecting and knowledge donating. Knowledge collecting is a shared understanding in gathering information from employees, consumers and other related parties by using knowledge networks for the benefit of the organization. Knowledge donating is a shared understanding in providing information to employees, consumers and other related parties by using a network of knowledge to achieve organizational goals. (Glassman \& Honeycutt, 2002; Kosasih, 2007). Some previous studies explained that entrepreneurial orientation and innovation continuously have a key role in improving the performance of SMEs (Boso et al., (2013); Mason et al., (2015); Santosa and Natsir, 2015).

Based on the literature mentioned, it could be seen that entrepreneurial orientation, knowledge sharing, and innovation capability affect business performance. Specific and convincing studies also show that knowledge sharing has a positive and significant impact on innovation capability and ultimately results in increased business performance (Lin, 2007; Wang \& Wang, 2012). Furthermore, entrepreneurial orientation also has a positive influence on innovation capability (Huang \& Wang, 2011; Shan, Song, \& Ju, 2016). In this study, the entrepreneurial orientation and knowledge sharing variables were modeled as independent variables and business performance as the dependent variable with innovation capability as a mediating variable. The model developed will provide valuable information on how much the portion of entrepreneurial orientation and knowledge sharing on innovation capability will end in business performance.

\section{Research Method}

This study uses a quantitative approach to the results obtained from samples that represent the population studied. Researcher describe quantitatively regarding some trends, behaviors, or opinions of a population by examining samples from the population. In this case the researcher collected data in the form of responses through questionnaires filled by business owners in the SMEs creative industry sector related to entrepreneurial behavior towards the ability of entrepreneurs to innovate and the performance of SMEs which were then quantified and analyzed and found important findings regarding research problems. This research focuses on knowledge sharing that can create the ability of innovation to create performance in order to compete with other companies.

This study uses path analysis to find explanations about the patterns of direct and indirect relationships based on theoretical considerations. Knowledge from researchers is displayed in the form of images (path diagrams / path diagrams) that serve to help in conceptualizing complex problems and to recognize the empirical and 
theoretical implications that were being tested (Sarwono, 2006). The reason for using path analysis in this study was to find out the direct and indirect effects of each variables tested.

In this study the researcher took a sample of the creative industry of Dinoyo Micro Small and Medium Enterprises in Dinoyo Village, Malang City. The reason for choosing the location of the study in that place was because the business had been around since 1953. As the development of the dinoyo ceramics business period was able to compete and survive with the onslaught of its competitors. The total sample taken by researcher were 57 Dinoyo Ceramic SME's owners.

\section{Result and Discussion}

Based on the data obtained, the number of respondents in this study was 57 respondents who were business owners of the Dinoyo ceramic creative industry in Malang City. The majority of respondents in this study were 33 women (57\%) from 57 people. Respondents in this study aged $41-50$ years were 23 people or $40 \%$. high school is the last level of education for the majority of Dinoyo Ceramic MSME business owners in Malang, which amounted to 41 respondents (71\%). The length of their business mostly have been established for 31-40 years.

The accuracy of the hypothetical model of the research data is measured from the relationship of the coefficient of determination $\left(R^{2}\right)$ on the two equations. The results of the accuracy of the model is $79,2 \%$. It can be seen that the contribution model to explain the structural relationship between the four variables studied is $79.2 \%$, it shows that the model used in this study is appropriate and able to explain the relationship of each variable used, leaving only $20.8 \%$ described by other variables because they are not included in this research model

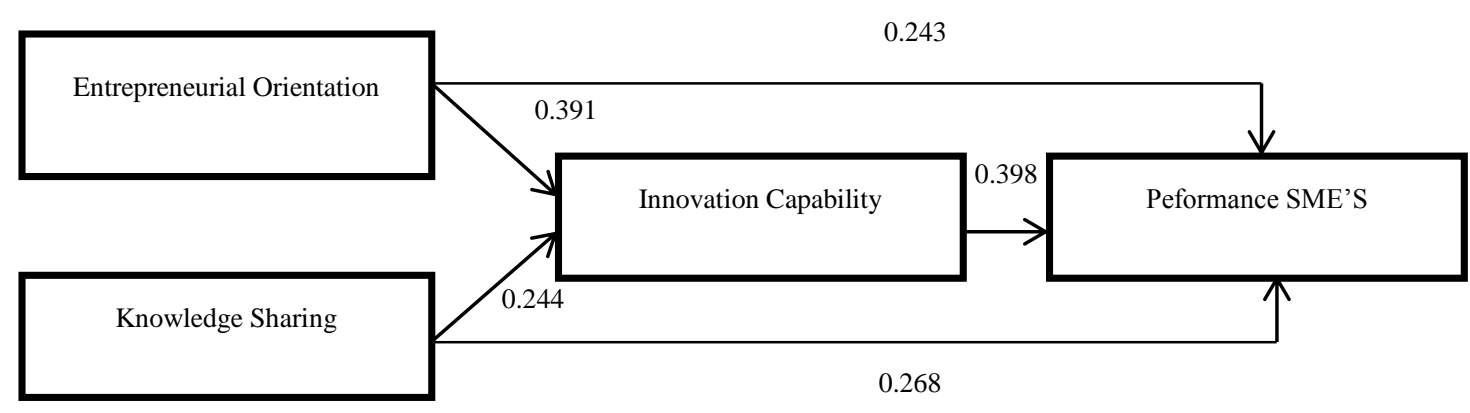

Fig. 1 Result of the structure of the equation model

The results of this study indicate that entrepreneurial orientation and knowledge sharing have a significant effect on innovation capability and the performance of small and medium enterprises in Dinoyo ceramics in Malang City, both directly and indirectly. Entrepreneurial orientation is an important factor because Dinoyo ceramics SMEs can conduct business activities that must be owned and applied by entrepreneurs, to get good performance. Entrepreneurial orientation that is supported by knowledge sharing among SMEs can enhance the ability to innovate so that the products produced are diverse and able to compete in the market so that the perceived impact is to improve the 
performance of SMEs.

This finding shows that the better entrepreneurial orientation found in Dinoyo Ceramic SMEs, the innovation capability tends to be better. This is in line with many research which explains that, to be successful, a profit organization requires autonomy from strong leaders or creative individuals, without restrictions imposed by the company's bureaucracy (Newbert 2008). Dinoyo creative SMEs industries can exploit valuable combinations of resources which competitors do not do. Therefore, entrepreneurial orientation as a method, practice and decision-making style of business owners using entrepreneurial actions is an effort from the strategic level to direct their resources so as to produce competitive advantage (Jantunen, et al., 2005).

Azadehdel (2013) states that the results of his research show that sharing knowledge by gathering small industries has a significant effect on all types of innovations and handicrafts, while contributing knowledge, involving donating inside and outside the group, has no effect on exploration innovation. Creativity needed for innovation comes from both clear and visible expertise, and also from accumulation seen from experience (Seidler-de Alwis and Hartmann, 2008). Every time employees share real organizational experience and accumulated knowledge with others. Creativity and innovation can also be improved. This research is in line with (Fen Lin, 2007; Mehrabani, 2012; Alhusseini, 2013) There is a relationship between knowledge and quality of innovation with the quality of innovation and the performance of trading and industrial companies (Azadehdel, 2013).

Salim and Sulaiman (2011) which explain that there is a significant influence between Innovation Capability and SMEs Performance. These findings prove that organizational learning contributes to the ability of innovation that is positively related to company performance. Innovation is a new idea that is applied to initiate or improve a product or process or service in a small and medium industry. This means that the better entrepreneurial orientation can improve business performance. A study explaining that there is a significant effect of entrepreneurial orientation on business performance. The SME industry that adopts Entrepreneurial Orientation can see business opportunities better than those who do not have such an orientation (Rauch., et al, 2009).

This shows that more and more knowledge sharing is carried out positively influences the performance of SMEs. The results of research in Dinoyo's creative ceramics industry show that knowledge sharing between SMEs is in the form of (information, skills, and expertise) to other people, friends, colleagues, superiors, subordinates, community and fellow SMEs engaged in Dinoyo Ceramics, Malang City. The results of this study support the research of Rudiyanto (2012) who explained that knowledge sharing affects employee performance positively and significantly in improving business performance. This means that the better the knowledge sharing, the better the business performance. In other words, to produce good performance, the company needs a good system. This system is not only an existing or standard regulation but also involves related parties directly to human resources. One of management systems that offers a discipline that treats intellectuals as managed assets is called knowledge management (Glassman \& Honeycutt, 2002). 


\section{Conclusions}

Suggestions that can be given in this study, namely paying attention to the development of information technology at this time is very quite developed with the hope that SMEs can market their products independently by selling digitally and not relying on direct marketing. SMEs are also hoping to be independent by continuing to increase their entrepreneurial spirit which is able to take risks and be keen to see opportunities. The hope is that MSMEs can also be able to continue innovating and synergizing with companies that have advanced by holding festivals or exhibitions to introduce their products in the community, especially at tourism events or bazaars related to creative industry SMEs.

The limitations of this study are that this study still examines the effect of entrepreneurial orientation, knowledge sharing, and the ability to take the initiative on the performance of the Dinoyo Ceramics Small and Medium Industries in Malang City. In the future, other studies can examine the impact of information technology on business performance because digital developments currently have a significant impact on sales growth. This study uses a sample of 57 respondents, so that future research can be considered to increase the number of samples.

\section{References}

Asegaff dan Wasitowati. 2015. "Knowledge Sharing Sebagai Sumber Inovasi dan Keunggulan Bersaing pada Usaha Mikro Kecil dan Menengah (UMKM) Sektor Batik". $2^{\text {nd }}$ Conference in Business, Accounting, and Management. 2(1), 208-221.

Azadehdel. M.R., F.Farahbod., M.A. Jamshidinejad, 2013, The Relationship between Knowledge Sharing, Innovation and Performance of Manufacturing and Trading Companies in Guilan Province, Interdisciplinary Journal of Contemporary research in Business, 5 (5), 408-412.

Boso, Nathaniel, Vicky M. Story, John W. Cadogan. 2013. Entrepreneurial Orientation, Market Orientation, Network Ties, and Performance: Study of Entrepreneurial Firms in a Developing Economy. Journal Of Business Venturing.Journal of Business Venturing JBV-05667; No of Pages 20 (2013).

Fen Lin, H. 2007. Knowledge Sharing and Firm Innovation Capability: An Empirical Study, International Journal of Manpower, 28 (3/4), 315-332.

Glassman, Myron \& Honeycutt, Earl D. 2002. "The Effects of Culture and Human Resources Management Policies on Supply Chain Management Strategy". Journal of Business Logistics. 23 (1) : 11-17.

Glassman, Myron \& Honeycutt, Earl D. 2002. “The Effects of Culture and Human Resources Management Policies on Supply Chain Management Strategy". Journal of Business Logistics. 23 (1) : 11-17.

Jantunen, A., Puumalinen, S., Samisarenketo, \& Kylaheiko, K. 2005. Entrepreneurial orientation dynamic capabilities, and international performance. Journal of International Entrepreneurship, (3): 223-243.

Huang, S. K., \& Wang, Y.-L. (2011). Entrepreneurial orientation, learning orientation, and innovation in small and medium enterprises. Procedia - Social and Behavioral Sciences, 24, 563-570. https://doi.org/10.1016/j.sbspro.2011.09.004 
Kosasih Natalia. 2007. Pengaruh Knowledge Management Terhadap Kinerja Karyawan : Studi Kasus Departemen Front Office Surabaya Plaza Hotel. Jurusan Manajemen Perhotelan Program Studi Manajemen Fakultas Ekonomi Universitas Kristen Petra Surabaya. Jurnal Manajemen Perhotelan, 3:2 (2007) 80-88.

Lin, H. F. (2007). Knowledge sharing and firm innovation capability: An empirical study. International Journal of Manpower. https://doi.org/10.1108/01437720710755272

Li, Y.-H., Huang, J.-W., dan Tsai, M.-T. 2009. “Entrepreneurial orientation and firm performance: The role of knowledge creation process". Industrial Marketing Management, 38(4), 440-449.

Mason, Michela C., Floreani, Josanco.,Miani, Beltrame, Federico., Roberto, Cappelletto, 2015. Understanding The Impact of Entrepreneurial Orientation on SME'S's' Peformance. The Role of The Finance Structure. Procedia Economics and Finance 23, 1649-1661.

Newbert, L. S. 2008. Value, rareness, competitive advantage, and performance: A conceptual-level empirical investigation of the resources-based view of the firm. Strategic Management Journal.29: 745-768.

Ngah. R., K. Jusoff., 2009, Tacit Knowledge Sharing and SME'S's' Organizational Performance, International Journal of Economics and Finance, 1(1), 216-220.

Preda, Gheorghe. 2013. "The Influence of Entrepreneurial Orientation and Market-Based Organizational Learning On The Firm's Strategic Innovation Capability". Management \& Marketing Challenges for the Knowledge Society, 8(4), 607-622.

Rauch, A., Wiklund, J., Lumpkin, G. T. and Frese, M., 2009. Entrepreneurial Orientation and Business Performance: An Assessment of Past Research and Suggestions for the Future. Entrepreneurship Theory and Practice, 33 (3): 761-787.

Robbins, Sp dan judge. 2002. Perilaku Organisasi Buku 2, Jakarta : Salemba Empat Hal 283.

Salim, Islam, M., and Sulaiman, M. 2011. “Organizational Learning, Innovation, and Performance: A Study of Malaysian Small and Medium Sized Enterprises". International Journal of Business and Management, 6(12), 118-125.

Santosa, Mulato dan Natsir, Muhammad. 2015. Pemediasian Keunggulan Bersaing dan Pembelajaran Organisasional Terhadap Hubungan Orientasi Kewirausahaan dengan Kinerja. ISSN 2460-0784.234-248.Seminar Nasional dan The $2^{\text {nd }}$ Call for Syariah Paper.

Sarwono, Jonathan. 2006. Metode Penelitian Kuantitatif \& Kualitatif, Yogyakarta.

Seidler-de Alwis, Ragna and Hartmann, Evi. 2008. "The Use of Tacit Knowledge Within Innovative Companies. Knowledge Management in Innovaive Enterprises" Journal of Knowledge Management, 12(1)133-147.

Shan, P., Song, M., \& Ju, X. (2016). Entrepreneurial orientation and performance: Is innovation speed a missing link? Journal of Business Research. https://doi.org/10.1016/j.jbusres.2015.08.032

Suliswanto, M. S. W., \& Rofik, M. (2019). Digitalization of Micro, Small \& Medium Enterprises (MSMEs) In East Java, Indonesia. Muhammadiyah International Journal of Economics and Business, 2(1), 34-43. https://doi.org/10.23917/mijeb.v2i1.9380

Wang, Z., \& Wang, N. (2012). Knowledge sharing, innovation and firm performance. Expert Systems with Applications. https://doi.org/10.1016/j.eswa.2012.02.017 
Wood, M.T. Gadd K., \&Falkenburg, D. 2004. Entrepreneurship for engineers. In: The NCIIA 8th Annual Meeting, March 18-20, Greenfield. 131-135.

Yuyus, Suryana \& Kartib, Bayu. 2010. Kewirausahaan : Pendekatan Karakteristik Kewirausahaan Sukses. Jakarta : Kencana. 
